\title{
Increasing growth rate of Verruconis gallopava, could it be one of the factors supporting its pathogenicity in warm blooded- animals?
}

\author{
K. Samerpitak ${ }^{1 *}$, A.H.G. Gerrits van den Ende ${ }^{2}$ and G.S. de Hoog ${ }^{2}$ \\ ${ }^{1}$ Departmant of Microbiology, Faculty of Medicine, Khon Kaen University, Khon Kaen, Thailand \\ ${ }^{2}$ Westerdijk Fungal Biodiversity Institute, Utrecht, the Netherlands \\ * Presenting author
}

\section{Objectives}

To investigate the growth rate behaviors of $V$. gallopava in varied temperatures.

\section{Materials and Methods}

1. Nineteen strains of $V$. gallopava were grown on malt extract agar (MEA) plates $\left(90 \mathrm{~mm}\right.$ in diam.) and incubated at $24^{\circ} \mathrm{C}$ for $14 \mathrm{~d}$.

2. Preparation of the circular inocula ( $2 \mathrm{~mm}$ in diam.) by using a metallic puncture tube.

3. The inocula were grown in duplicate on MEA plates and incubated for $3 \mathrm{wk}$ at the temperatures varied from 4 to $40^{\circ} \mathrm{C}$ with mostly $3^{\circ} \mathrm{C}$ interval.

4. Colony diameters were measured after incubation for $3,7,11$, 14,18 , and 21 days.

5. The growth rates in all investigated temperatures were calculated and compared by Microsoft Excel and T-test.

\section{Results}

1. The growth of all $V$. gallopava strains could not be observed at the temperatures lower than $15^{\circ} \mathrm{C}$ (Fig 1).

2. The growth of colonies was significantly increased at $3^{\circ} \mathrm{C}$ interval in the range of $18-37^{\circ} \mathrm{C},(\mathrm{t} \geq \mathrm{ta0} .05)$ (Fig 1).

3. No significant difference of growth was detected between $9^{\circ} \mathrm{C}$ to $15^{\circ} \mathrm{C}$, and $37^{\circ} \mathrm{C}$ to $40^{\circ} \mathrm{C}$, ( $\left.\mathrm{t}=\mathrm{ta} 0.05\right)$ (Fig 1$)$.

4. The lowest growth rate was $0.01 \mathrm{~mm} /$ day at $15^{\circ} \mathrm{C}$, and the highest was $6.20 \mathrm{~mm} /$ day at $37^{\circ} \mathrm{C}$, and the growth increased depending on time and temperature at the average rate of $0.28 \mathrm{~mm} /$ day $/{ }^{\circ} \mathrm{C}$ (Table 1 , Fig 2 ).

5 . The differences of the growth rates compared between the low temperatures viz. $15^{\circ} \mathrm{C}, 18^{\circ} \mathrm{C}, 21^{\circ} \mathrm{C}, 24^{\circ} \mathrm{C}, 27^{\circ} \mathrm{C}, 30^{\circ} \mathrm{C}, 33^{\circ} \mathrm{C}$ and the higher temperatures showed an average growth rate of 354.2X, 21.1X, 6.9X, 2.9X. 1.7X, 1.4X and 1.1X, respectively $(\mathrm{X}=$ times) (Table 1$)$.

Fig 1 Average colony diameters of $V$. gallopava, 19 strains, grown on MEA, at temperatures varied from $4{ }^{\circ} \mathrm{C}$ to $40^{\circ} \mathrm{C}$, after incubation for 3,7 , $11,14,18$ and 21 days

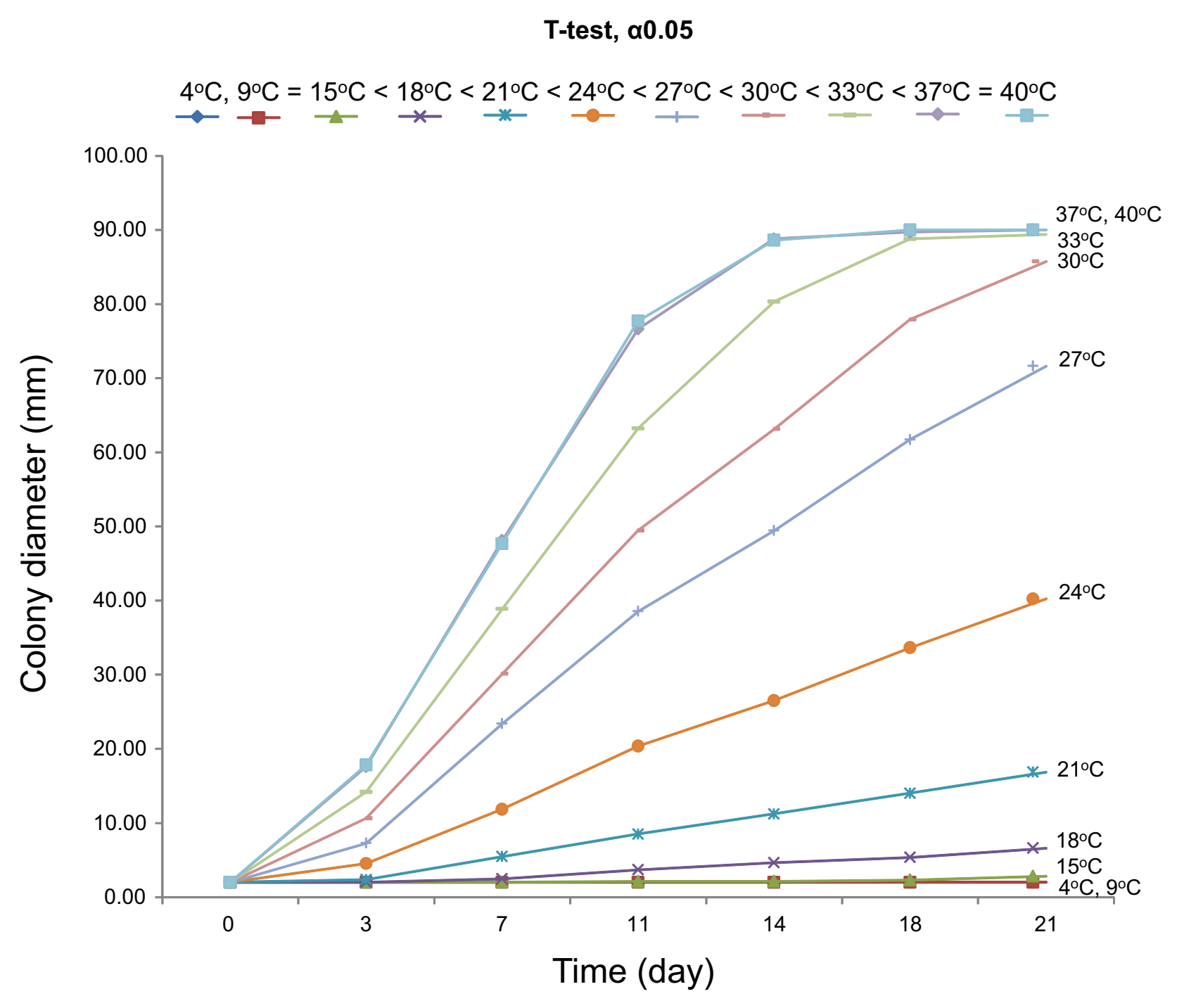

\section{Conclusion}

1. The growth ability of $V$. gallopava starts at $15^{\circ} \mathrm{C}$ and higher.

2. The growth rate was depending on both time and temperature, and the average rate was $0.28 \mathrm{~mm} /$ day $/{ }^{\circ} \mathrm{C}$.

3. The optimal growth of $V$. gallopava showed at temperatures between $37^{\circ} \mathrm{C}$ and $40^{\circ} \mathrm{C}$.

4. The growth rate profile of the species could lead to hypothesize its growth and pathogenic behaviors as following;

a) The species could thrive in general environment with temperature ranging from $15^{\circ} \mathrm{C}$ to $40^{\circ} \mathrm{C}$.

b) The species could grow faster in natural hot environments and also inside the bodies of warm-blooded animals.

c) The different temperature between the strain's niche and body of warm-blooded animals could accelerate the strain's growth rate and enhance animal tissue invasion leading to finally successful infection.

These hypotheses should have to be further investigated.

Table 1 Comparison of $V$. gallopava growth rates $(G R)$ after incubations for 14 days at the temperatures varied from $15^{\circ} \mathrm{C}$ to $40^{\circ} \mathrm{C}$

\begin{tabular}{|c|c|c|c|c|c|c|c|c|c|}
\hline \multirow[t]{2}{*}{ Temp. } & \multirow{2}{*}{$\begin{array}{c}\text { GR } \\
(\mathrm{mm} / \text { day })\end{array}$} & \multicolumn{8}{|c|}{$\begin{array}{c}\text { GR at higher temp. / GR at lower temp. (X (times)), } \\
\text { when the lower ones are ; }\end{array}$} \\
\hline & & $15^{\circ} \mathrm{C}$ & $18^{\circ} \mathrm{C}$ & $21^{\circ} \mathrm{C}$ & $24^{\circ} \mathrm{C}$ & $27^{\circ} \mathrm{C}$ & $30^{\circ} \mathrm{C}$ & $33^{\circ} \mathrm{C}$ & $37^{\circ} \mathrm{C}$ \\
\hline $4^{\circ} \mathrm{C}$ & 0.00 & \multicolumn{8}{|c|}{ No growth } \\
\hline $9^{\circ} \mathrm{C}$ & 0.00 & \multicolumn{8}{|c|}{ No growth } \\
\hline $15^{\circ} \mathrm{C}$ & 0.01 & & & & & & & & \\
\hline $18^{\circ} \mathrm{C}$ & 0.19 & 18.93 & & & & & & & \\
\hline $21^{\circ} \mathrm{C}$ & 0.66 & 65.98 & 3.47 & & & & & & \\
\hline $24^{\circ} \mathrm{C}$ & 1.75 & 175.18 & 9.22 & 2.65 & & & & & \\
\hline $27^{\circ} \mathrm{C}$ & 3.39 & 338.93 & 17.84 & 5.14 & 1.94 & & & & \\
\hline $30^{\circ} \mathrm{C}$ & 4.37 & 436.79 & 22.99 & 6.62 & 2.50 & 1.29 & & & \\
\hline $33^{\circ} \mathrm{C}$ & 5.59 & 559.46 & 29.45 & 8.48 & 3.20 & 1.65 & 1.28 & & \\
\hline $37^{\circ} \mathrm{C}$ & 6.20 & 620.00 & 32.63 & 9.39 & 3.54 & 1.83 & 1.42 & 1.11 & \\
\hline $40^{\circ} \mathrm{C}$ & 6.19 & 618.57 & 32.56 & 9.37 & 3.53 & 1.82 & 1.42 & 1.11 & 1.00 \\
\hline $\begin{array}{l}\text { Average } \\
\left(15-40^{\circ} \mathrm{C}\right)\end{array}$ & 3.15 & 354.23 & 21.16 & 6.94 & 2.94 & 1.65 & 1.37 & 1.11 & 1.00 \\
\hline
\end{tabular}

Fig 2 Growth rates (GR) of $V$. gallopava at the temperatures varied from $4^{\circ} \mathrm{C}$ to $40^{\circ} \mathrm{C}$, after incubations for 14 days

\section{Growth rate $=0.28 \mathrm{~mm} /$ day $/{ }^{\circ} \mathrm{C}$}

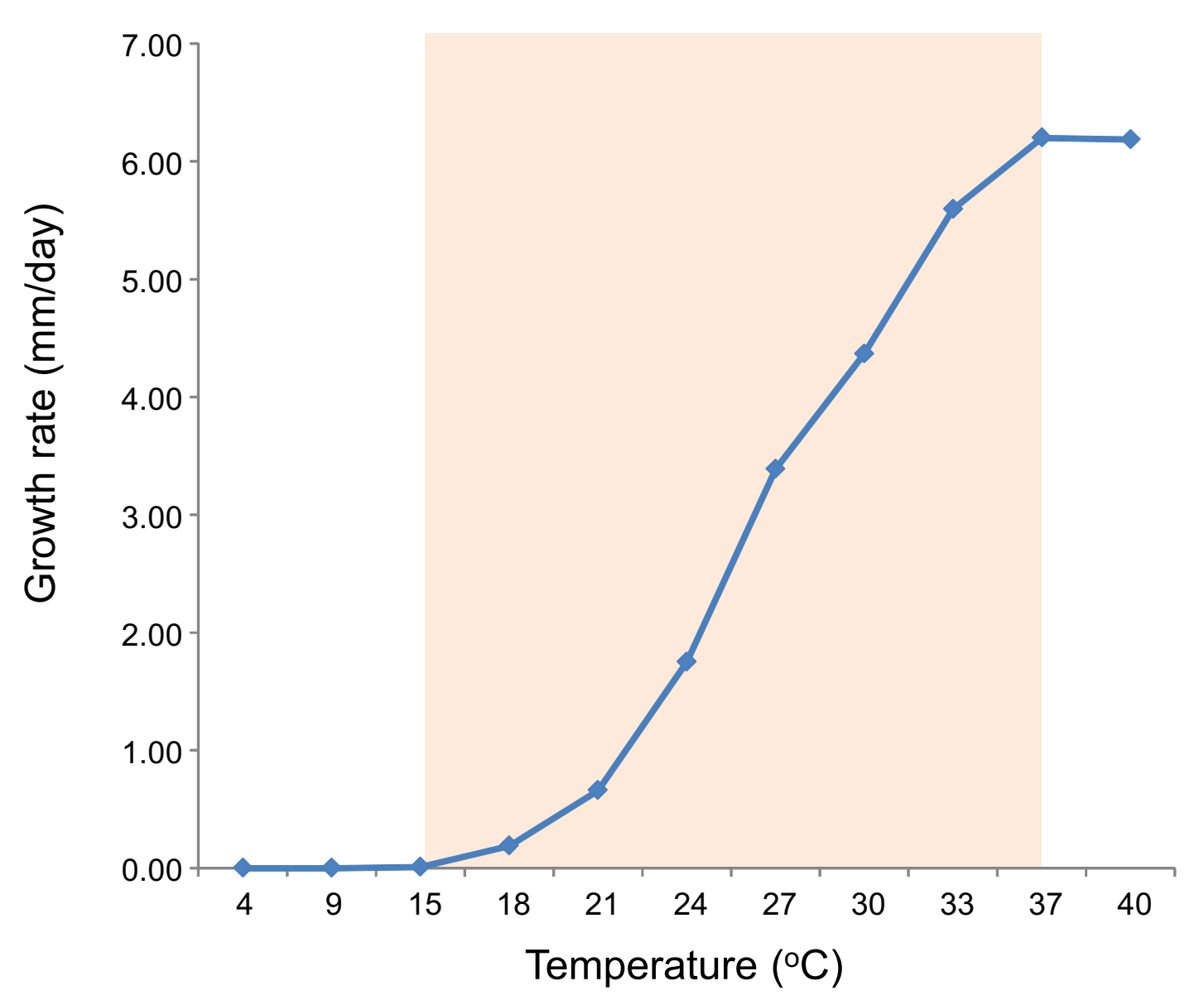

